\title{
The Effects of Growth Substances on Intercalary Growth and Cellular Differentiation in Developing Internodes of Avena sativa
}

\author{
I. The Effects of Indole-3-acetic Acid
}

\author{
By \\ Peter B. Kaufman \\ Department of Botany, University of Michigan, Ann Arbor, Michigan \\ (Received December 15, 1964)
}

\section{Introduction}

The causal basis for growth and cellular differentiation in grass internodes has received relatively little attention. Much of the emphasis has been on morphologic aspects of development (Kaufman et al. 1965). Questions of what factors control asymmetric cell division patterns and the direction of cell enlargement in the intercalary meristem, rates and duration of cell division and cell enlargement during intercalary growth, and the highly polarized pathway of growth and cellular differentiation characteristic of the grass internode have hardly been touched.

In this paper, two problems related to causal aspects of intercalary growth in Avena sativa internodes will be considered: (1) the effects of exogenously supplied indole-3-acetic acid (IAA) on linear growth and distribution of growth in long internodes of Avena and (2) the effects of IAA on cell division, cell enlargement, and cellular differentiation in the intercalary meristem of Avena internodes. Primary attention will focus on questions of causal aspects of polarized growth in the internode and the ways in which auxin can profoundly modify this growth pattern and pathways of cell division and enlargement that occur in the epidermal system of elongating internodes during intercalary growth. Corollary to this, data will be presented on the influence of light and dark on expression of IAA-induced modifications in growth and cellular differentiation in Avena internodes. 


\section{Material and Methods}

Various portions of the Avena shoot mentioned in this paper are presented in Figure 1. It will be useful to refer to this Figure in the methods cited below. For the sake of clarity, intercalary growth will be considered here as being composed of two facets: (1) cell division component, which is dominant during the first third of the period that intercalary growth takes place and (2) cell enlargement component, which is dominant during the last twothirds of the period. Both processes clearly overlap (Kaufman et al. 1965), and cellular differentiation occurs continually during both phases of growth.

Culture conditions for growth of Avena plants and methods for selecting shoots have been cited earlier (Kaufman et al. 1965). The green shoot portions are excised $1 \mathrm{~cm}$ below the p-1 node. The sheath surrounding $\mathrm{p}-1$ internode and inserted at $\mathrm{p}-1$ node (Figure 1) is carefully removed with a teasing needle simply by slitting successive longitudinal strips of sheath without injuring the enclosed internode. This was done to facilitate measurements of length and diameter of p-1 internode and for preparation of epidermal peels. The leaf surrounding the peduncle and inflorescence (last leaf in Figure 1) and inserted at the peduncular node was left intact. Each shoot was then inserted in a Pyrex glass tube $(10 \mathrm{~cm}$ long, $5 \mathrm{~mm}$ i.d.). This tube, in effect, serves as an artificial sheath and prevents curvature of $\mathrm{p}-1$ internode during its growth in vitro. It is well-known that developing grass internodes, devoid of their surrounding sheaths, are very fragile, especially in the intercalary meristem (I.M.) region.

The tube containing the excised shoot portion was then placed in a test-tube containing the incubation medium. This medium consisted of $1.5 \mathrm{ml} 0.1 \mathrm{M}$ fructose \pm IAA. Sugar generally increases stem elongation, and fructose is the best carbon

Figure 1. Diagram illustrating various portions of an excised Avena shoot. In p-1 internode, the primary subject of these studies, the course of growth and cellular differentiation is basipetal as indicated by arrow at left of p-1i. a: last leaf of shoot; $\mathrm{b}$ : inflorescence; $\mathrm{c}$ : peduncular internode $\left(\mathrm{p}^{\mathrm{i}}\right)$; $\mathrm{d}$ : peduncular node $\left(\mathrm{p}^{\mathrm{n}}\right)$; e: intercalary meristem zone (I.M.); f: p-1 internode $\left(\mathrm{p}-1^{\mathrm{i}}\right) ; \mathrm{g}$ : $\mathrm{p}-1$ node $\left(\mathrm{p}-\mathrm{1}^{\mathrm{n}}\right) ; \mathrm{h}$ : portion of $\mathrm{p}-2$ internode $\left(\mathrm{p}-2^{\mathrm{i}}\right)$.

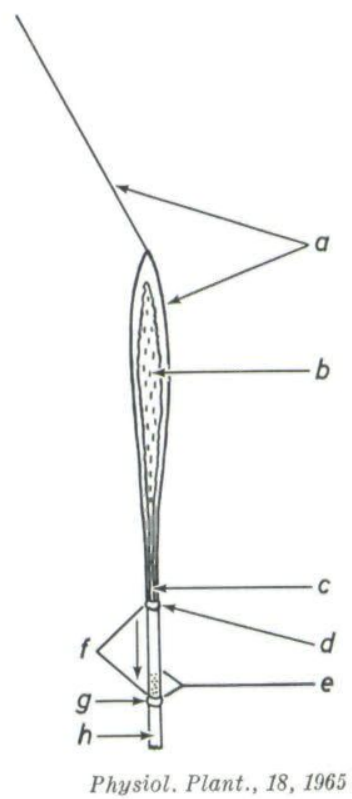


source for Avena stem segments (Kaufman et al. 1962). In order to simplify terminology in the text, the control medium, consisting of $0.1 M$ fructose, will be referred to as $-I A A$, and the medium which includes $0.1 M$ fructose + IAA will be referred to as $+I A A$.

Excised shoot portions were incubated in light or dark at $22.5^{\circ} \mathrm{C}$ for periods of 4 to 6 days. The light regime consisted of $18 \mathrm{hr}$ light, $6 \mathrm{hr}$ dark in $24 \mathrm{hr}$ cycles. The light intensity was 2000 lux.

In growth distribution experiments, the shoot portion with its exposed p-1 internode was marked with India ink under a dissecting microscope, using a no. 0 Leroy pen to apply successive dots of ink to the internode. The ink dots were placed $2 \mathrm{~mm}$ apart, starting $2 \mathrm{~mm}$ above the p-1 node (Figure 1) and continuing in a linear file to the top of the internode, just below p node. Earlier, internodes were marked with $\mathrm{Cu}_{2} \mathrm{O}$ as Castle (1955) did with Avena coleoptiles. It was found that $\mathrm{Cu}_{2} \mathrm{O}$ as well as $\mathrm{CuO}$ particles dusted uniformly over the surface of $\mathrm{p}-1$ internodes substantially repressed linear extension of the internode. Hence, the use of these compounds was abandoned. The inking procedure, in spite of inherent weaknesses, was used because experiments of this nature, if interpreted cautiously, yield additional information on the effect of IAA on polarized intercalary growth in p-1 internode.

Parameters of growth employed in these experiments included (1) rate of change and net change in length of p-1 internode, $(2)$ maximum diameter and dry weight of the internode at end of incubation period, (3) net change in distances between ink dots on marked internodes, and (4) changes in length, width, and number of cells in the epidermal system of $\mathrm{p}-1$ internode following incubation of shoots in presence and absence of IAA in light and dark. Linear growth and growth distribution measurements for dark-incubated shoots were recorded under a fluorescent lamp covered with one sheet each of green and amber "Cellon" plastic film. Internodal diameter was measured with a Vernier caliper. Procedures for preparation of epidermal peels and staining of fresh peels in acetocarmine are described in Kaufman et al. (1965). Photomicrographs were taken with Adox KB-14 film in an Exakta camera.

\section{Results}

\section{The effect of IAA on growth of p-1 internode in light and dark}

It has been reported by Thimann and Wardlaw (1963) that greater uptake of ${ }^{14} \mathrm{C}$-labelled IAA occurs in excised pea stem segments in the light compared with that in the dark. In order to determine if more profound alterations in linear and lateral growth could be elicited by IAA in long internodes of Avena shoots in the light, the following experiment was performed. Excised Avena shoots, with p-1 internode varying from 0.2 to $10.5 \mathrm{~cm}$ in length at time zero, were incubated in $0.1 M$ fructose $\pm I A A$ at $100 \mathrm{mg} / \mathrm{l}$ in the light. Comparable shoots were incubated in the same medium in the dark at $22.5^{\circ} \mathrm{C}$. The experiments were repeated three times with essentially the same results.

Representative data from these experiments (Figure 2) reveal the following: (1) For $-I A A$ shoots, there is a relatively sharp peak in linear growth of p-1 internode in the dark as contrasted with no such peak for p-1 interPhysiol. Plant., 18, 1965 


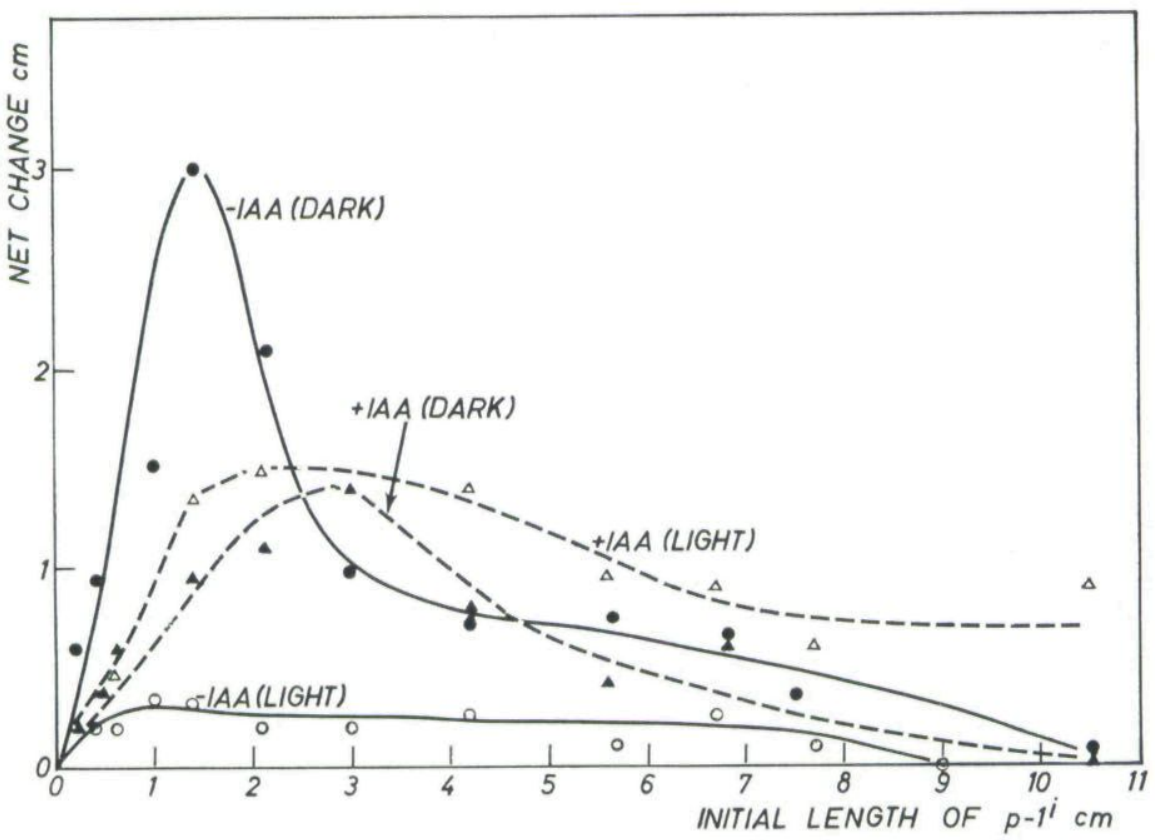

Figure 2. Net change in length of p-1 internodes of different stages of development in Avena shoots incubated in $0.1 \mathrm{M}$ fructose $\pm 1 \mathrm{AA}$ at $100 \mathrm{mg} / \mathrm{l}$ in light and dark for $96 \mathrm{hr}$ at $22.5^{\circ} \mathrm{C}$. Lengths of p-1 internode at time zero varied from 0.2 to $10.5 \mathrm{~cm}$.

nodes in light-incubated shoots. The maximum growth in the dark occurs when initial length of p-1 internode is ca. $1.5 \mathrm{~cm}$. It is also obvious for this treatment that light almost completely suppresses growth of $p-1^{i}$. (2) IAA elicits a greater linear growth response in p-1 internode in the light than in the dark for most stages of development of p-1 internodes. The maximal response to IAA in the light occurs when initial length of p-1 internode is between 1.5 and $4.0 \mathrm{~cm}$, corresponding to the time when epidermal cells in the internode are elongating most rapidly. The region of maximal response of p-1 internode to IAA in the light does not coincide with that for darkgrown -IAA shoots, but rather, occurs just after the dark peak. Also, the curve for $\mathrm{p}-1$ internode in $+I A A$ in the light represents more of a plateau response compared with the sharp peak in $-I A A$ shoots in the dark. (3) The maximal response of $\mathrm{p}-1$ internode to IAA in dark does not coincide with that for $-I A A$, dark-incubated shoots. Moreover, it is obvious that $+I A A$ in the dark has the effect of completely abolishing the peak growth response that occurs in p-1 internode in the dark at the stage when p-1 internode is ca. $1.5 \mathrm{~cm}$ long. This inhibitory effect of IAA on growth of p-1 internode in dark-incubated shoots is certainly just as significant as the promotive effect of IAA on growth of light-incubated shoots. The broad plateau effect of IAA in the light is not exhibited by dark-incubated shoots treated with IAA. It is thus apparent from these experiments that IAA at a relatively high exo- 


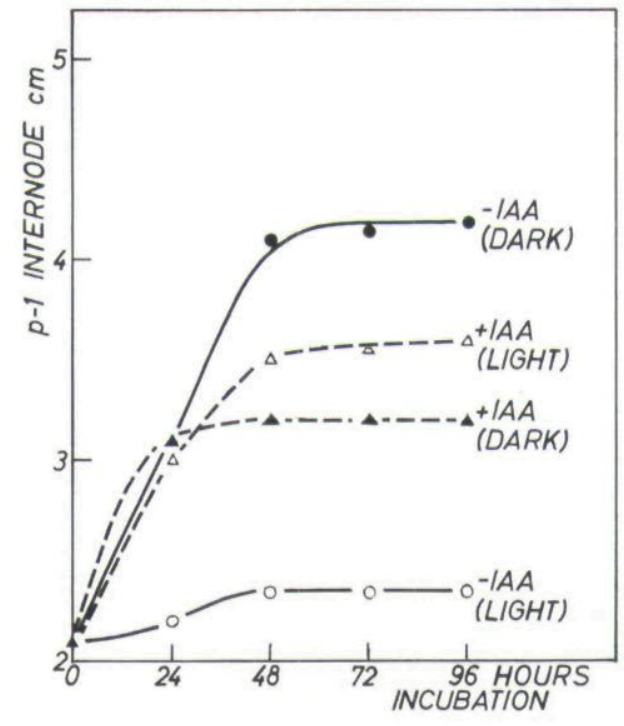

Figure 3. Time course of linear growth response of p-1 internode in excised Avena shoots to $0.1 \mathrm{M}$ fructose $\pm I A A$ at $100 \mathrm{mg} / \mathrm{l}$ in light and dark. Initial length of $\mathrm{p}-1$ internode for each treatment was $2.1 \mathrm{~cm}$. Shoots were incubated at $22.5^{\circ} \mathrm{C}$ for $96 \mathrm{hr}$.

genous concentration $(100 \mathrm{mg} / \mathrm{l})$ has two primary effects on the growth of p-1 internode in Avena: (1) it strongly promotes the longitudinal growth of the internode in the light and (2) it inhibits growth of p-1 internode in darkgrown shoots to the same level that it promotes growth in light-grown shoots. Similar responses have been observed for IAA at concentrations of 10 and $1 \mathrm{mg} / \mathrm{l}$. The responses are of lower orders of magnitude than those obtained with IAA at $100 \mathrm{mg} / \mathrm{l}$ (Table 1).

Figure 3 shows the time course responses of one series of internodes, initially $2.1 \mathrm{~cm}$ in length, to fructose \pm IAA at $100 \mathrm{mg} / \mathrm{l}$ in light and dark. The curves indicate that rate of growth for both $\pm I A A$, dark-incubated shoots is nearly the same and occurs at a constant rate during the first $24 \mathrm{hr}$. After $24 \mathrm{hr}$, growth in the $+I A A$, dark-incubated shoot levels off earliest, next for the $+I A A$, light-incubated shoot, and last for the $-I A A$, darkincubated shoot. The rate of growth for the $-I A A$, light-incubated shoot is ca. $1 / 10$ that of the other three shoots during the first $24 \mathrm{hr}$. Thus, from these data, it is evident that IAA causes an acceleration of growth of p-1 internode in the light, the effect taking place immediately from time zero and terminating by $48 \mathrm{hr}$ with internodes of this particular length. The duration of IAA-induced acceleration of growth is longer (up to $72 \mathrm{hr}$ ) for older internodes and ca. the same for younger ones. They also very succinctly demonstrate the IAA-induced suppression of growth in dark-incubated shoots, an effect which appears within $24 \mathrm{hr}$ after shoots are first incubated and is as profound as the IAA-induced acceleration of growth in p-1 internode in the light.

In addition to promoting linear growth of p-1 internode in the light, IAA also causes a significant increase in diameter of the internode in the locus of the I.M. This effect can be observed in the dark for a fairly wide concen- 
Table 1. Effect of various concentrations of IAA on maximum diameter, dry weight, and net change in length of p-1 internodes of excised Avena shoots incubated in the dark for $120 \mathrm{hr}$. Mean values for 20 shoots. Initial length of $\mathrm{p}-1 \mathrm{i}=1.85 \mathrm{~cm}$. Maximum standard error of mean internodal diameter was $\pm 0.01 \mathrm{~mm}$. Measurements were made ca. $0.5 \mathrm{~cm}$ above base of p-1 internode. Average dry weight per shoot for 20 shoots.

\begin{tabular}{|c|c|c|c|}
\hline Treatment & $\begin{array}{c}\text { Max. diameter } \\
\mathrm{mm}\end{array}$ & $\begin{array}{c}\text { Dry weight } \\
10^{-3} \cdot \mathrm{g}\end{array}$ & $\begin{array}{l}\text { Net change in } \\
\text { length of } p-1 \mathrm{i} \\
\mathrm{cm}\end{array}$ \\
\hline $\begin{array}{l}-I A A \\
+I A A \text { at } 1 \mathrm{mg} / \mathrm{l} \ldots \ldots \ldots \\
+I A A \text { at } 10 \mathrm{mg} / \mathrm{l} \ldots \ldots \ldots \\
+I A A \text { at } 100 \mathrm{mg} / \mathrm{l} \ldots \ldots \ldots\end{array}$ & $\begin{array}{l}1.8 \\
2.1 \\
2.3 \\
2.7\end{array}$ & $\begin{array}{l}5.3 \\
5.3 \\
6.1 \\
7.5\end{array}$ & $\begin{array}{l}0.45 \\
0.50 \\
0.60 \\
0.95\end{array}$ \\
\hline
\end{tabular}

Table 2. Effect of presence and absence of IAA (at $100 \mathrm{mg} / \mathrm{l}$ ) on maximum diameter, dry weight, and net change in length of p-1 internodes of Avena following incubation of excised shoots in light and dark for $72 \mathrm{hr}$. Mean values for 20 shoots. Length of p-1i at time zero $=1.55 \mathrm{~cm}$. Measurements of max. diameter were made ca. $0.5 \mathrm{~cm}$ above base of $\mathrm{p}-1 \mathrm{i}$. No significant difference occurs for diameters in $-I A A$, light and dark-incubated shoots. Average dry weight per shoot for 20 shoots.

\begin{tabular}{|c|c|c|c|}
\hline Treatment & $\begin{array}{l}\text { Max. diameter } \\
\mathrm{mm}\end{array}$ & $\begin{array}{c}\text { Dry weight } \\
10^{-3} \cdot \mathrm{g}\end{array}$ & $\begin{array}{l}\text { Net change in } \\
\text { length of } p-1 i \\
\mathrm{~cm}\end{array}$ \\
\hline 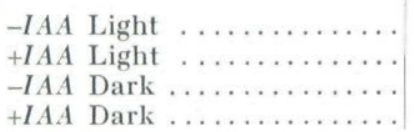 & $\begin{array}{l}1.8 \pm 0.006 \\
2.5 \pm 0.010 \\
1.8 \pm 0.007 \\
2.3 \pm 0.011\end{array}$ & $\begin{array}{l}6.2 \\
8.4 \\
4.8 \\
7.3\end{array}$ & $\begin{array}{l}0.20 \\
0.65 \\
0.72 \\
0.59\end{array}$ \\
\hline
\end{tabular}

tration range of IAA (Table 1 ). The same relationship holds true for $\mathrm{p}-1$ internode at other stages of development, i.e., when initial length of $\mathrm{p}^{-1^{\mathrm{i}}}$ is $<$ or $>1.85 \mathrm{~cm}$. The increase in diameter of $\mathrm{p}-1$ internode elicited by IAA is most strongly expressed in the light (Table 2). These observed effects of IAA on length and diameter of p-1 internode in the light point to the possibility that perhaps more exogenously supplied auxin is actually transported to the I.M. region in $\mathrm{p}-1^{\mathrm{i}}$ of excised shoots incubated in the light than in the dark.

\section{Effect of IAA on distribution of growth in p-1 internode of Avena shoots}

Growth distribution in p-1 internode in response to incubation of excised shoots in fructose \pm IAA in the light and dark was investigated by means of the marking procedure cited earlier. Data in Figure 4 reveal that at a stage when p-1 internode shows the greatest differential in linear growth between light and dark treatments, when $\mathrm{p}^{-{ }^{\mathrm{i}}}$ is ca. $2 \mathrm{~cm}$ in length, the primary sites where linear extension takes place in the dark are intervals 1 and 2, located at the I.M. locus and lying at the extreme base of the internode just above p node (Figure 1). No such polarized linear growth response was observed for light-incubated shoots. In these, extension occurred in four intervals with 


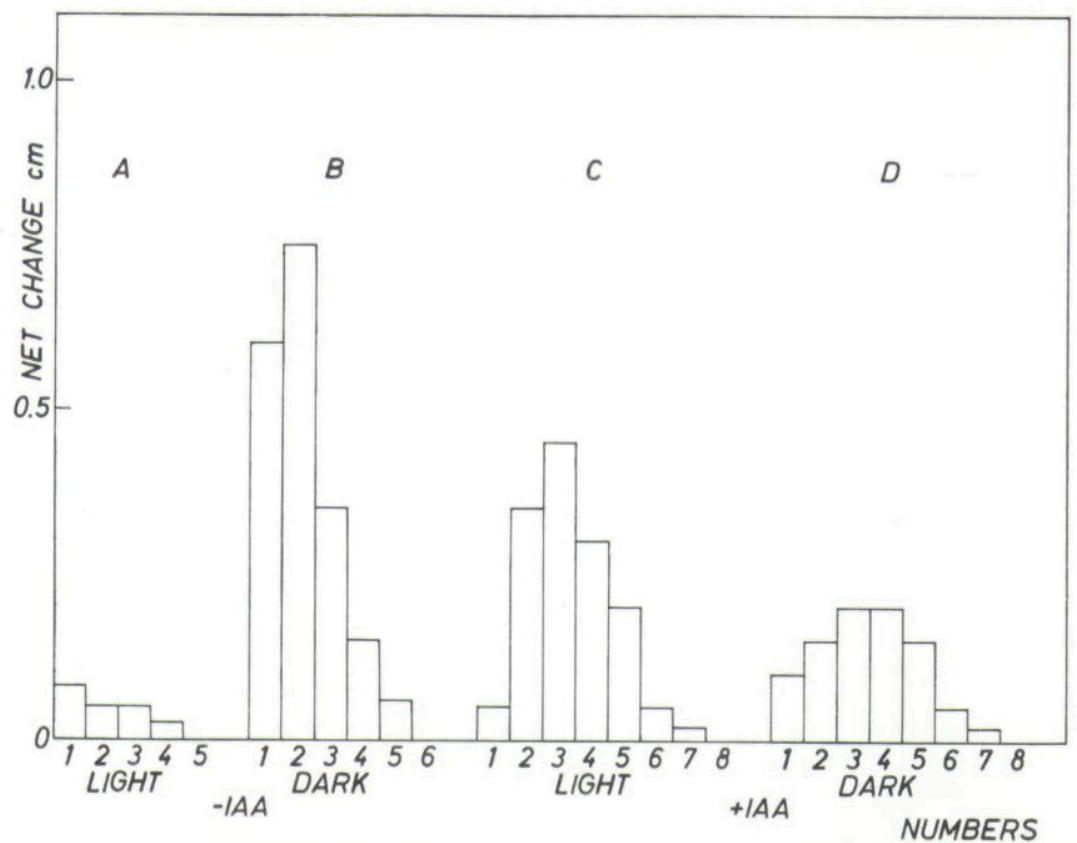

Figure 4. Net change in interval lengths in p-1 internodes incubated in $+I A A(100 \mathrm{mg} / \mathrm{l})$ and -IAA solutions in light and dark at $22.5^{\circ} \mathrm{C}$ for $96 \mathrm{hr}$. Interval no. 1 is at base of $\mathrm{p}-1 \mathrm{i}$, no. 2 just above no. 1, etc. Initial length of each interval $2 \mathrm{~mm}$. Initial and final lengths of p-1 internode for each treatment were as follows: (A) p-1i: $2 \rightarrow 2.3 \mathrm{~cm}$; (B) p-1i: $2.1 \rightarrow 4.2$ $\mathrm{cm}$; (C) p-1i: $2.1 \rightarrow 3.6 \mathrm{~cm}$; (D) p-1i: $2.1 \rightarrow 3.2 \mathrm{~cm}$.

somewhat greater extension taking place in interval 1 (Figure 4). Extension in intervals 1 and 2 for $-I A A$, dark-incubated shoots begins during the first $24 \mathrm{hr}$, during which time the increment is doubled. However, maximal rate of extension in these shoots occurs between 24 and $48 \mathrm{hr}$, when the increment of growth increases to levels 4 to 5 times that at time zero. In contrast, in light-incubated shoots, the increment of growth for intervals 1 and 2 is only about 1.12 after $24 \mathrm{hr}$ and only 1.25 after $48 \mathrm{hr}$. In connection with the IAA treatments (Figure 4), it is clear that IAA at $100 \mathrm{mg} / \mathrm{l}$ affects a larger number of marked intervals than in shoots incubated in the absence of IAA. The intervals which manifest the greatest change in length in IAAtreated shoots are number 3 (light-incubated shoots) and numbers 3 and 4 (dark-incubated shoots). These are above the locus of greatest linear growth response (intervals 1 and 2 ) for $-I A A$, dark-incubated shoots. The growth promotion elicited by IAA that occurs in intervals 2 to 5 (Figure 4 ) is much more striking in the light than in the dark, again reflecting the promotion of growth in and above the I.M. zone in p-1 internode by IAA in the light and inhibition of growth in p-1 internode in approximately the same locus by IAA in the dark (compare with data in Figure 2).

In Table 3 is a fractional representation of the number of $2 \mathrm{~mm}$ intervals in which longitudinal extension occurs after $96 \mathrm{hr}$ of incubation compared Physiol. Plant., 18, 1965 
Table 3. Number of $2 \mathrm{~mm}$ intervals which change in length compared with total number of $2 \mathrm{~mm}$ intervals in marked p-1 internodes of Avena after $96 \mathrm{hr}$ of incubation in $0.1 \mathrm{M}$ fructose $\pm I A A$ at $100 \mathrm{mg} / \mathrm{l}$ in light and dark. Light = $18 \mathrm{hr}$ light, $6 \mathrm{hr}$ dark, $24 \mathrm{hr}$ cycles. Dark $=$ continuous darkness.

\begin{tabular}{|c|c|c|c|c|}
\hline $\begin{array}{c}\text { Initial length } \\
\text { of } \mathrm{p}-1 \text { internode } \\
\mathrm{cm}\end{array}$ & $\begin{array}{c}-I A A \\
\text { Light }\end{array}$ & $\begin{array}{c}+I A A \\
\text { Light }\end{array}$ & $\begin{array}{c}-I A A \\
\text { Dark }\end{array}$ & $\begin{array}{c}+I A A \\
\text { Dark }\end{array}$ \\
\hline & & & & \\
0.2 & $1 / 1$ & $1 / 1$ & $1 / 1$ & $1 / 1$ \\
0.4 & $2 / 2$ & $2 / 2$ & $2 / 2$ & $2 / 2$ \\
1.6 & $2 / 3$ & $3 / 3$ & $3 / 3$ & $3 / 3$ \\
1.4 & $3 / 5{ }^{1}$ & $4 / 5$ & $3 / 5$ & $5 / 5$ \\
2.1 & $4 / 7$ & $5 / 7$ & $5 / 7$ & $5 / 7$ \\
3.0 & $4 / 8$ & $7 / 8$ & $5 / 8$ & $7 / 8$ \\
4.2 & $4 / 15$ & $7 / 15$ & $6 / 15$ & $6 / 15$ \\
5.7 & $4 / 21$ & $8 / 21$ & $4 / 21$ & $6 / 21$ \\
7.7 & $3 / 28$ & $7 / 28$ & $5 / 28$ & $5 / 28$ \\
10.5 & $3 / 33$ & $7 / 33$ & $4 / 33$ & $5 / 33$ \\
& $2 / 38$ & $6 / 38$ & $3 / 38$ & $4 / 38$ \\
& $0 / 52$ & $6 / 52$ & $3 / 52$ & $4 / 52$ \\
\hline
\end{tabular}

${ }^{1} 3 / 5$ means that three intervals out of total of five intervals changed in length after $96 \mathrm{hr}$ of incubation of $\mathrm{p}-1$ internode.

with the total number of $2 \mathrm{~mm}$ intervals for marked internodes at different stages of development in shoots incubated in media \pm IAA (IAA at $100 \mathrm{mg} / \mathrm{l}$ ) in the light and dark. The following observations can be made from these data: First, for p-1 internodes $<1 \mathrm{~cm}$ in length at time zero, essentially all of the intervals change in length irrespective of the treatment. At these stages, the entire internode is involved in intercalary growth. Second, in -IAA, darkincubated shoots, usually one or two more intervals are involved in linear growth than in $-I A A$, light-incubated shoots. This means that a greater portion of the internode at any particular time is involved in intercalary growth in the dark than in the light. Perhaps this is a reflection of the effect of light in accelerating cellular differentiation during the development of the internode as has been pointed out for pea internodes by Thompson and Miller (1963). Third, the number of intervals in which a change in length occurs is substantially greater for IAA-incubated shoots in both light and dark than in those incubated in -IAA medium in light and dark. Fourth, it is evident that the fraction of the internode involved in linear growth diminishes in a continuous fashion with increase in length of p-1 internode, a trend which verifies the gradual localization of the intercalary growth zone to the base of the internode as it increases in age. The interesting fact here is that IAA has an effect of reversing this trend as seen by the large number of intervals which change in length in older internodes incubated in $+I A A$ medium in the light (Table 3 ). Thus IAA, in effect, (1) prolongs intercalary growth in the internode and completely overcomes the effect of light in suppressing internodal extension during later stages of development of the internode and (2) it nearly abolishes the very intensive intercalary growth that is characteristic of dark-incubated internodes in early stages of elongation. 


\section{Effect of IAA on patterns of cell division, cell enlargement and cellular differentiation in p-1 internode of Avena}

IAA causes several profound changes in patterns of cellular differentiation above the I.M. in the epidermis of Avena internodes. (For a comparison with patterns of cellular differentiation in internodal epidermis of untreated p-1 internodes of Avena, one should refer to the paper by Kaufman et al. 1965, and to Figure 11.) The primary alterations include (1) promotion of cell elongation in long epidermal cells with concommitant enlargement of these cells perpendicular to the long axis of the internode (Figure 5), (2) induction of supplementary longitudinal divisions (supplementary division here refers to a longitudinal division which occurs in a long epidermal cell that has undergone lateral expansion in response to IAA; such divisions do not occur in long epidermal cells in untreated internodes) in long epidermal cells which normally would never divide once formed by asymmetric divisions in I.M. initials (Figure 6), and (3) change in polarity of cell division in short epidermal cells, resulting in the formation of pairs of cork and silica cells or stomates which are at right angles to their normal plane of orientation (Figure 7). These changes in patterns of cellular differentiation were first observed to occur within $24 \mathrm{hr}$ after Avena shoots were first incubated in $+I A A$ medium. The initial response is cell enlargement in initials of the I.M. followed by the supplementary longitudinal divisions in the long cell derivatives. These alterations are most obvious in shoots incubated in the light in $+I A A$ solutions at stages when IAA most strongly promotes longitudinal and lateral growth in p-1 internode $(\mathrm{p}-1$ internode $=1$ to $3 \mathrm{~cm}$ in length at time zero). They occur with less frequency at lower concentrations of IAA and in shoots at stages where IAA most strongly suppresses growth of p-1 internode in the dark (p-1 internode $=2$ to $4 \mathrm{~cm}$ in length at time zero).

The most striking alterations in plane of cell division and cell enlargement in the epidermis of $\mathrm{p}-1$ internode were observed in cell rows which lie directly over a vascular bundle and the 2 to 3 rows of cells which lie immediately adjacent to such a bundle. The significance of this observation is that a gradient in response of cells to exogenous IAA can be traced from the vascular bundle, where the alterations are most profound, to the intervascular cell rows, where the response is almost negligible.

The swelling or lateral growth that takes place at the site of the I.M. in internodes of IAA-incubated shoots is due primarily to lateral cell enlargement in I.M. cells and their derivatives. Coupled with this, but of secondary importance, are the supplementary longitudinal divisions that occur in long cell members of the epidermal system. It is interesting to point out here that colchicine $(0.2$ per cent in $0.1 M$ fructose) will also elicit substantial cell

Figures 5-7. Photomicrographs illustrating some primary effects of exogenously supplied $I A A$ on differentiating epidermal cells in p-1 internode of Avena. Shoots from which peels were made were incubated in the light for 24 to $36 \mathrm{hr}$ at $22.5^{\circ} \mathrm{C}$. Figure 5 is at level of the I.M. Figures 6 and 7 occur at two levels just above the I.M. with Figure 7 at level slightly higher than that in Figure 6. Interpretations in text. Drawing at left of each photomicrograph indicates alterations elicited by IAA - s.l.d., supplementary longitudinal division; l.c., long epidermal cell; s.c., subsidiary cell; t.d., transverse division; g.c., guard cell. All $\times 430$.

Physiol. Plant., 18, 1965 

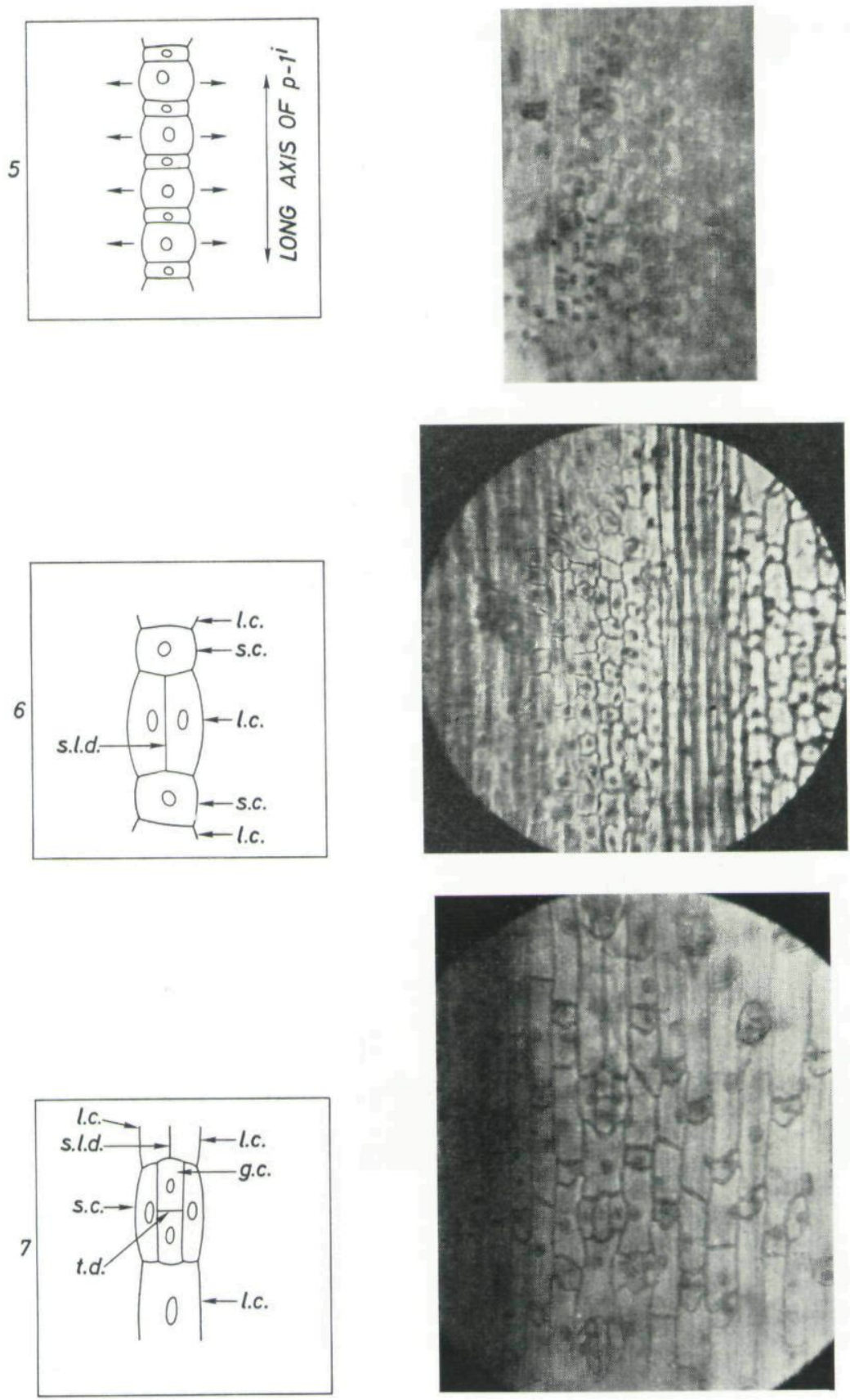

Figures 5-7. 

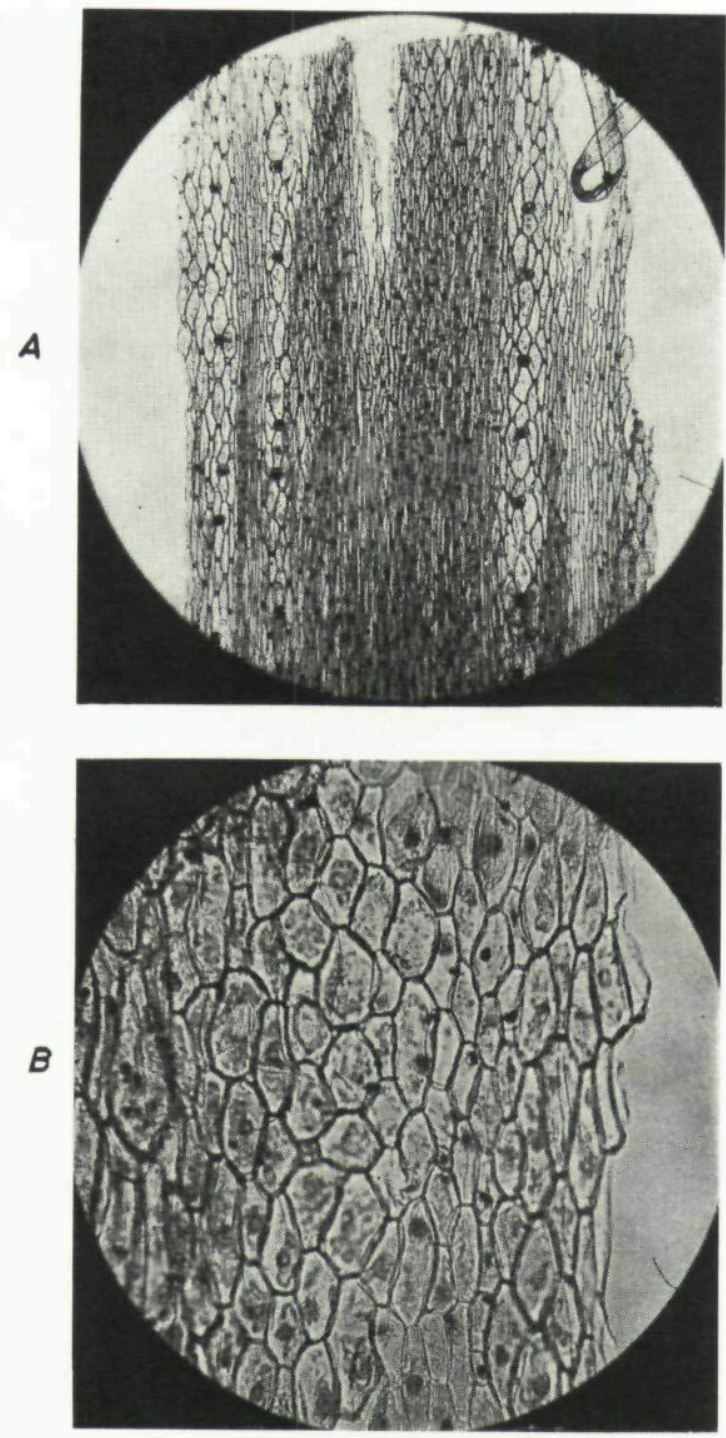

Figure 8. A-B. Epidermal peels from p-1 internode of Avena shoots incubated in $0.1 \mathrm{M}$ fructose + colchicine at 0.2 per cent for $72 \mathrm{hr}$ at $22.5^{\circ} \mathrm{C}$ in the dark. Peels show greatly increased diameter of long epidermal cells. Diameter of this internode was $3.3 \mathrm{~mm}$ at end of incubation period compared with $2.7 \mathrm{~mm}$ for comparable fructose-incubated shoots. A: $\times 100$. B: $\times 430$.

enlargement in long cell members of the epidermal system but without causing additional longitudinal divisions (Figure $8 \mathrm{~A}$ and $\mathrm{B}$ ). These responses in Avena cells to colchicine are similar to those observed by Green (1963) in Nitella internodal cells.

The primary morphogenetic question here in connection with IAA is whether IAA causes cell enlargement prior to the time that additional divisions occur in long epidermal cells or whether these divisions precede any obvious promotion in cell enlargement. The evidence here strongly supports Physiol. Plant., 18, 1965 
Table 4. Lengths and widths of cells and number of cells per $5 \mathrm{~mm}$ in the intercalary meristem of p-1 internodes at two stages of development in excised Avena shoots cultured in $0.1 M$ fructose $\pm I A A$ (at $100 \mathrm{mg} / \mathrm{l}$ ). Light treatment: $18 \mathrm{hr}$ light, $6 \mathrm{hr}$ dark, 2000 lux, $22.5^{\circ} \mathrm{C}$. Mean values for 20 measurements.

\begin{tabular}{|c|c|c|c|c|c|c|}
\hline \multirow[b]{2}{*}{$\begin{array}{l}\text { Treatment and } \\
\text { incubation time }\end{array}$} & \multicolumn{3}{|c|}{ Length of $\mathrm{p}-1$ internode, $\mathrm{cm}$} & \multicolumn{3}{|c|}{ Mean values } \\
\hline & $\begin{array}{l}\text { Initial } \\
\text { length }\end{array}$ & $\begin{array}{l}\text { Final } \\
\text { length }\end{array}$ & $\begin{array}{l}\text { Net change } \\
\text { in length }\end{array}$ & $\begin{array}{c}\text { Cell length } \\
\mu\end{array}$ & $\begin{array}{c}\text { Cell width } \\
\mu\end{array}$ & $\begin{array}{l}\text { Cell num- } \\
\text { ber per } \\
5 \mathrm{~mm}\end{array}$ \\
\hline$-I A A$ Light $(63 \mathrm{hr})$ & 1.4 & 1.6 & 0.2 & $24.9 \pm 1.25$ & $12.1 \pm 0.59$ & $6.9 \pm 0.18$ \\
\hline$+I A A$ Light $(63 \mathrm{hr})$ & 1.4 & 3.2 & 1.8 & $54.9 \pm 2.44$ & $16.2 \pm 0.59$ & $3.3 \pm 0.18$ \\
\hline$-I A A$ Light $(57 \mathrm{hr})$ & 3.8 & 3.9 & 0.1 & $42.3 \pm 1.96$ & $9.3 \pm 0.23$ & - \\
\hline$+I A A$ Light $(57 \mathrm{hr})$ & 3.8 & 4.8 & 1.0 & $47.7 \pm 2.29$ & $13.2 \pm 0.98$ & \\
\hline
\end{tabular}

the idea that the additional divisions elicited by IAA occur after the cells have enlarged laterally. The primary data in support of this contention are found in Table 4 . These data show that the cells in the I.M. which give rise to long and short epidermal cells in IAA-incubated shoots average 1.3 to 1.5 times the width of cells in control $(-I A A)$ shoots. These are the cells which divide asymmetrically at right angles to the long axis of the internode, a particular division giving rise to one long and one short epidermal cell. In none of these cells were any supplementary longitudinal divisions observed. It was only after the I.M. cells had divided asymmetrically and the resultant long cells had enlarged laterally that any additional longitudinal divisions were seen. This sequence of events is diagrammed and described in Figure 9.

The increase in length of p-1 internode elicited by IAA in the light is due in part to an increase in length of cells of the I.M. which give rise to long and short epidermal cells (Table 4). I.M. cells in $+I A A$, light-incubated shoots may be as much as twice as long as comparable cells in -IAA, lightincubated shoots $\left(e . g .\right.$, where $\mathrm{p}-1^{\mathrm{i}}=1.4 \mathrm{~cm}$ in length at time zero, data cited

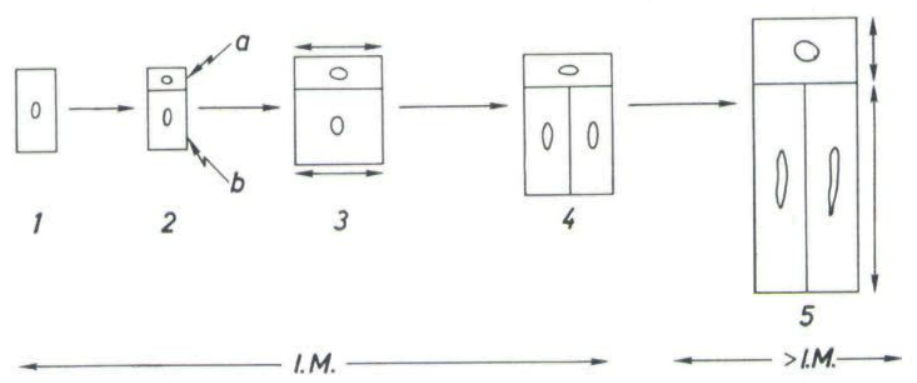

Figure 9. Sequence of events in IA.1-treated Avena shoots leading to formation of supplementary longitudinal division in long epidermal cell in I.M. of p-1 internode: I.M. cell (1) in which occurs an asymmetric division (2) followed by IAA-induced lateral cell enlargement (3) in products of this division. Supplementary longitudinal division then occurs in long cell member of pair (4). Cell elongation than follows in all three cells (5) i.e. the short cell and pair of long epidermal cells. a, b: short and long cell members, respectively. 
Table 5. Comparison of lengths and widths of long and short epidermal cells in middle portion of $p-1$ internode of excised Avena shoots incubated in $0.1 \mathrm{M}$ fructose $\pm I A A$ at $100 \mathrm{mg} / \mathrm{l}$ in the light. Light treatment: $18 \mathrm{hr}$ light, $6 \mathrm{hr}$ dark, $24 \mathrm{hr}$ cycles. Incubation time: $63 \mathrm{hr}$. Mean values for 20 measurements, 4 rows of cells, 5 cells per row, all at same level of p-1i. Short cells: Combined lengths of pairs of cork and silica cells which occur in $-I A A$ shoots. In $+I A A$ shoots, values represent lengths of single, undivided short cells.

\begin{tabular}{|c|c|c|c|c|c|c|}
\hline \multirow[b]{2}{*}{ Treatment } & \multicolumn{3}{|c|}{ Length of p-1 internode, $\mathrm{cm}$} & \multicolumn{2}{|c|}{ Mean cell length, $\mu$} & \multirow{2}{*}{$\begin{array}{l}\text { Mean cell width, } \mu \\
\text { Long cells }\end{array}$} \\
\hline & $\begin{array}{l}\text { Intial } \\
\text { length }\end{array}$ & $\begin{array}{l}\text { Final } \\
\text { length }\end{array}$ & $\begin{array}{c}\text { Net } \\
\text { change in } \\
\text { length }\end{array}$ & Long cells & Shor & \\
\hline $\begin{array}{l}-I A A \quad . \\
+I A A \quad \ldots\end{array}$ & $\begin{array}{l}1.4 \\
1.4\end{array}$ & $\begin{array}{l}1.6 \\
3.2\end{array}$ & $\begin{array}{l}0.2 \\
1.8\end{array}$ & $\begin{array}{l}117.30 \pm 6.85 \\
169.95 \pm 7.85\end{array}$ & $\begin{array}{l}13.95 \pm 0.31 \\
20.79 \pm 0.69\end{array}$ & $\begin{array}{l}15.60 \pm 0.35 \\
18.99 \pm 0.55\end{array}$ \\
\hline
\end{tabular}

at top of Table 4). The effect of IAA on elongation of I.M. cells is less significant in older internodes (e.g., where p-1 internode $=3.8 \mathrm{~cm}$ in length at time zero, data cited in lower portion of Table 4). In the dark, IAA actually suppresses cell elongation at stages where it also suppresses internodal extension. For example, in p-1 internodes initially $0.5 \mathrm{~cm}$ in length, it was found that after $48 \mathrm{hr}$ in the dark, $-I A A$ internodes were $0.8 \mathrm{~cm}$ long with epidermal cells in the I.M. averaging $33.67 \mu$ in length and $11.19 \mu$ in width. $+I A A$ internodes were $0.7 \mathrm{~cm}$ in length after $48 \mathrm{hr}$, and I.M. epidermal cells averaged $26.46 \mu$ in length and $18.87 \mu$ in width. In comparable light-incubated members of this series, data for the $-I A A$ internodes were as follows: length of $\mathrm{p}-1$ internode $=0.5 \mathrm{~cm}$, average length of I.M. epidermal cells = $22.20 \mu$, width $=11.03 \mu$. For the $+I A A$ internodes, length after $48 \mathrm{hr}=0.9 \mathrm{~cm}$, length of I.M. epidermal cells $=42.55 \mu$, and width $=24.24 \mu$.

Subsequent elongation of long and short epidermal cells above the I.M. in IAA-treated shoots, between 24 and $48 \mathrm{hr}$ after shoots are first incubated, contributes most significantly to the increase in length of p-1 internode elicited by IAA in the light. Both types of cells, for example, may be ca. 1.5 times longer than those in untreated shoots as shown by data in Table 5 . These long and short epidermal cells, in which a promotion in linear extension takes place, were found to occur at higher levels in IAA-treated shoots than in control shoots, particularly with older shoots incubated in the light.

There is essentially no difference in number of long epidermal cells in continuous rows of cells that extend from the top to the base of p- 1 internode in $-I A A$ and $+I A A$-incubated shoots. For example, in p-1 internodes initially $1.5 \mathrm{~cm}$ in length at time zero, after $40 \mathrm{hr}$ of incubation in the light, the number of epidermal cells in one continuous file was 337 in the $-I A A$ shoot and 353 in the $+I A A$ shoot. Similar results were obtained for internodes at other stages of development.

One other observation that is pertinent here is that short cells in the I.M. of $+I A A$-incubated shoots often fail to divide, and instead, elongate as shown by a comparison of lengths of these single undivided cells $(+I A A)$ and combined lengths of pairs of cells that had divided $(-I A A)$ in Table 5 . This failure of many short cells to divide in p-1 internode of IAA-treated shoots accounts for the substantial amount of suppression in stomate differentia- 
tion that was observed in epidermal peels derived from the I.M. locus of these internodes. The extent of repression of stomate differentiation that was observed was as great as 27 per cent, based upon counts of numbers of stomates in continuous epidermal cell files extending from $\mathrm{p}^{\mathrm{n}}$ to $\mathrm{p}-1^{\mathrm{n}}$ in $-I A A$ and $+I A A$-incubated shoots.

\section{Discussion}

Two primary questions raised by the current investigations will be considered in this discussion. First, what is the causal basis for the effect of IAA on intercalary growth in elongating internodes of the oat plant? Second, how does one explain modifications in patterns of cellular differentiation elicited by IAA in the epidermal system of developing Avena internodes?

\section{The causal basis for the effect of IAA on intercalary growth in Avena internodes}

It has been clearly demonstrated by Thimann and Wardlaw (1963) with ${ }^{14} \mathrm{C}$-labelled IAA that there is more net uptake of labelled IAA from agar blocks by illuminated green pea segments than by segments maintained in the dark, irrespective of the polarity of the segment. The work of Hashimoto (1959) and of Scott and Briggs (1963) also support these findings in more indirect fashion. In the present studies with excised Avena shoots incubated in the light and dark for periods up to $72 \mathrm{hr}$, it was found (Figure 3) that exogenously supplied IAA caused an acceleration of linear extension and prolonged intercalary growth in p-1 internode in the light, whereas in the dark, it actually suppressed the rate and amount of extension in the internode. This evidence would suggest that in the light, compared with dark, a greater amount of IAA, or some active form of auxin derived from it, arrives at the site of the I.M. near the base of the internode, where the primary acceleration in linear and lateral growth take place. Two possible explanations can be posed here: (1) either more effective uptake and/or acropetal transport of IAA by excised Avena shoots takes place in the light or (2) light-induced destruction of IAA in the illuminated shoots could be the primary basis for the differences observed. The latter possibility implies that light-incubated shoots may be more auxin-limited due to light destruction of native auxin than those maintained in the dark, where inhibition of growth could occur with added increments of exogenous IAA. Answers to these possible explanations will have to await more critical analysis using isolated segments, ${ }^{14} \mathrm{C}$-labelled IAA, and auxin diffusion and extraction procedures.

The fact that IAA accelerates cell enlargement to different extents depending on stage of development in elongating Avena internodes can be shown by comparing data on changes in cell number and cell length during intercalary growth in untreated internodes from intact shoots (adapted from Kaufman et al. 1965) with the effects of IAA on these components of growth in p-1 internodes in excised Avena shoots. Such a comparison is depicted in Figure 10. The most obvious fact from this comparison is that IAA has 


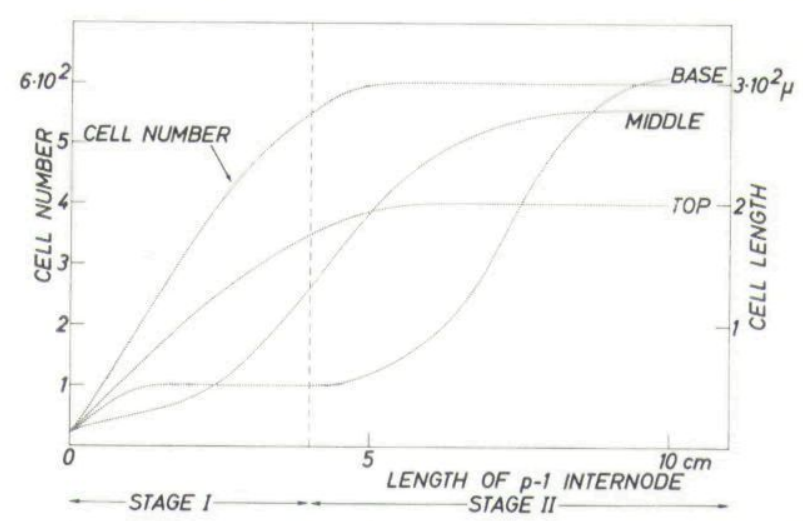

Figure 10. Changes in cell number and cell length in epidermal system in untreated p-1 internodes of light-grown intact Avena shoots at different stages of development of the internode (from Kaufman et al. 1965). Increase in cell number is primarily due to occurrence of asymmetric divisions in I.M. cells.

Stage I $(0-4 \mathrm{~cm})$. - Cell division component of intercalary growth dominant. Cells of I.M. cease dividing, begin to enlarge, and undergo differentiation after p-1 internode is 3.5 to $4.0 \mathrm{~cm}$ in length. Processes of cell division and cell enlargement are overlapping.

During Stage I, IAA strongly promotes lateral and longitudinal cell enlargement. This promotion is strongly expressed in the light and is most striking in the I.M. In dark, cell elongation is suppressed by IAA whereas lateral cell enlargement is augmented but not as positively as in the light. IAA has no significant effect on rate of formation of asymmetric divisions or on total number of cells formed by these divisions in I.M. cells.

Stage II $(4-11 \mathrm{~cm})$. - Cell enlargement component of intercalary growth dominant.

During this stage, IAA less strongly promotes cell enlargement. Intercalary growth is prolonged by IAA. - The effects of IAA are based upon data from the present paper.

its greatest effect on intercalary growth during early stages of development of p-1 internode ( 0 to $4 \mathrm{~cm}$ in length) while the cell division component of intercalary growth is still dominant. The paradox here is that IAA has essentially no effect on either the intensity or the absolute number of asymmetric divisions in the I.M., but does affect the direction and extent of enlargement of the cells in which asymmetric divisions occur as well as in the products of these divisions. During the time after p-1 internode has completed slightly more than one-third of its growth (4 to $10 \mathrm{~cm}$ length of p-1 internode), when cell elongation is dominant, IAA also promotes elongation of both short and long epidermal cells. However, the relative amount of promotion of cell elongation by IAA in older internodes (at the site where the I.M. was once active) on an individual cell basis is not as great as in the I.M. of younger internodes (compare data, Tables 4 and 5). But, as mentioned earlier, the extent of the zone where promotion of cell elongation takes place is much greater in older internodes than in younger ones when they are incubated in the light. Perhaps the differences in responses of individual cells might be explained on the basis of the internode being strongly auxin-limited during early stages of development and much less so later. On the other hand, it could also be due to the possibility that the enlargement facet of growth in I.M. initials is more sensitive to IAA than it is in the long cell Physiol. Plant., 18, 1965 
derivatives of these initials. Evidence from other workers' investigations (Burström 1942, Miller and Miller 1964, Purves and Hillman 1958, Torrey 1963) suggests that there are profound differences in sensitivity of cells to auxin within different tissue systems as well as during different stages of ontogeny in the same tissue or organ. That such differences might prevail in elongating Avena internodes is highly possible on the basis of evidence cited in this paper. The responses of dividing cells in the intercalary meristem to IAA are very strongly expressed in terms of accelerated cell enlargement in both transverse and longitudinal directions, as contrasted with elongating and differentiating cells above the I.M., where the acceleration of cell enlargement by IAA is much less striking (compare Tables 4 and 5 and Figures 5 and 7). Also, in older internodes, after cell division has ceased in the intercalary meristem, and all of the cells in the lower portion of the internode are enlarging and differentiating, there is a much more subdued response to IAA as expressed by less increase in amount of cell enlargement than in p-1 internodes that are much younger (Fig. 2, Tables 4 and 5). Thus, the author favors the view, on the basis of this evidence, that cells in the same internode and in internodes at different stages of development do, in fact, show a differential in sensitivity to IAA and particularly when cell division component of intercalary growth is dominant in the intercalary meristem. Perhaps endogenous auxin itself in the intact internode has a similar effect and has a controlling influence on the intensity and duration of cell enlargement during intercalary growth.

\section{Modifications elicited by IAA in patterns of cellular differentiation in inter- nodal epidermis of $p^{-1} 1^{i}$ of Avena}

Exogenous auxin has been shown in the current investigations to have a profound effect on cell enlargement in I.M. initials in the basal portions of rapidly elongating Avena internodes. It may also evoke some rather striking changes in plane of cell division in long and short cell derivatives of I.M. initials. But, interestingly, IAA does not disturb to any marked extent the plane or frequency of transverse asymmetric divisions that occur in I.M. initials, divisions which mark the first stages of cellular differentiation above the intercalary meristem. These proceed in normal fashion even in the presence of greatly augmented cell enlargement in I.M. initials when IAA is added to the system at physiologically high concentrations.

Alterations induced by IAA in patterns of cell enlargement and in patterns of cell division, which bring about increase in length and width of p-1 internode, are summarized in Figure 11. Also presented in this Figure is a comparison with the normal pathway of cellular differentiation that occurs above the I.M. in internodal epidermis. The alterations in patterns of cell division elicited by IAA in Avena internodal epidermis include: (1) supplementary longitudinal divisions in elongating epidermal cells and (2) change in plane of cell division in guard cell mother cells and in cork cell-silica cell initials. One might expect either of these two types of alterations in cell division patterns as a consequence of the substantial amount of promotion in cell enlargement in both long and short cells by IAA, especially in the transverse direction. It is important to stress that this augmented cell enlargement 


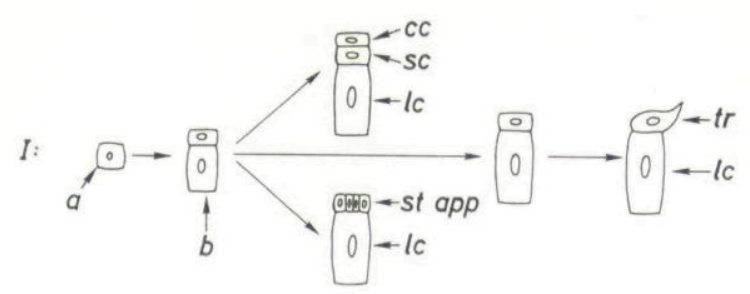

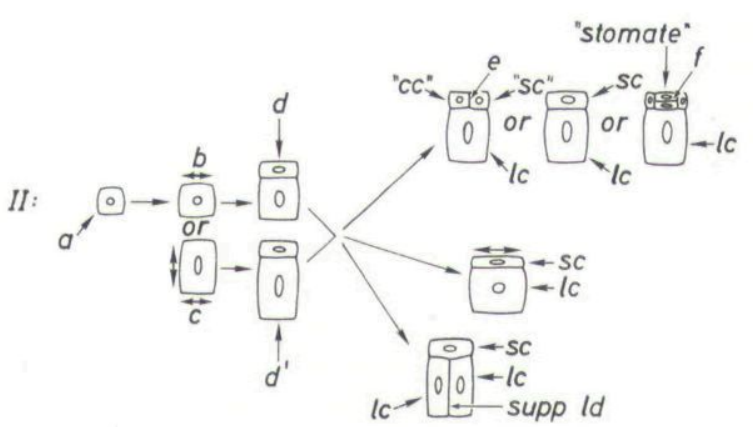

Figure 11. Comparison of normal (I) and IAA-altered (II) pathways of cellular differentiation in internodal epidermis of $p-1$ internode of Avena shoots. Explanation in text. - cc, cork cell: $s c$, silica cell; lc, long cell; st app. stomate apparatus; $t r$, trichome: supp ld, supplementary longitudinal division; in pathway $\mathrm{I}$ : (a) I.M. cell, (b) asymmetric division; in pathway II; (a) I.M. cell, (b) lateral expansion, (c) lateral and longitudinal expansion, (d) asymmetric division, (e,f) change in polarity of division.

precedes any alterations in cell division patterns. This is compatible with evidence already presented by Burström (1942), Levan (1939), and Kaufman (1955) for roots, Jablonski and Skoog (1954) for tobacco pith, Adamson (1962) for Jerusalem artichoke tuber tissue, and Ruge (1937) and Diehl et al. (1939) for Helianthus hypocotyls. These investigations have also shown that IAA or related hormones (e.g., NAA, 2,4-D) may cause changes in plane of cell division or direction of cell enlargement. In roots, the changes in plane of cell division and promotion of transverse growth in cortical derivatives of the root apex, as elicited by exogenously supplied hormones, are as striking as the alterations described here in Avena internodes.

The effect of IAA on transverse cell enlargement in cells of the intercalary meristem of young rapidly elongating Avena internodes is particularly significant. Initials in the I.M. are extremely responsive to IAA during cell division component of intercalary growth. They enlarge to diameters 1.5 to 3 times those of cells in untreated internodes within as short a period as $24 \mathrm{hr}$ after shoots are first incubated in $0.1 \mathrm{M}$ fructose + IAA at $100 \mathrm{mg} / \mathrm{l}$. These responses are most obvious adjacent to vascular bundles which underlie the epidermal system. Differentiating long and short epidermal cells above the I.M. are also not immune to this promotion by IAA of transverse enlargement of the cell. Such an effect of IAA on transverse enlargement of the cell is compatible with evidence presented by Diehl et al. (1939) and by Burström (1942) that an enlarging rectangular cell tends to enlarge at a faster rate in the transverse direction than in the longitudinal direction. The effect of IAA on I.M. cells in Avena internodes can thus be visualized as one of augmenting this differential in rates of lateral and longitudinal enlarge- 
ment in the cell. Moreover, it is the author's contention that it is this early promotion of lateral cell enlargement by IAA in and just above the I.M. that causes the alterations in cell divisions cited above. The basic mechanism involved here is not clear, but on a biophysical basis alone, one might expect that a long or short cylinder which undergoes any substantial transverse expansion would show a tendency to divide into two compartments in elements still capable of undergoing division. Such a model was proposed earlier by Burström (1942) and is supported by evidence from the current investigations on Avena internodes.

The other facet of this question of cell enlargement is the fact that IAA also causes a substantial increase in amount of cell elongation both in I.M. initials and in elongating cells above the I.M. This would be expected in light of similar evidence obtained by many other workers (e.g., Allsopp 1954 with Marsilea sporelings, Burström 1942 and Hejnowicz 1961 with Triticum roots, Jackson 1960 with Agrostis root hairs, Miller and Miller 1964 with Onoclea gametophytes, Ruge 1937 and Diehl et al. (1939) with Helianthus hypocotyls). One might here ask the question whether native auxin itself exerts a controlling action in maintaining a balance between transverse and lateral growth of the cell while the cell is in an active state of division (e.g. I.M. initials) and while it is enlarging after divisions have ceased (e.g., epidermal cells above the I.M.). Evidence from the current studies with exogenous auxin indirectly tends to support this thesis. Could it be that in the intact system high levels of native auxin promote transverse cell expansion whereas lower levels promote cell elongation? The studies here show that the promotion of transverse growth of cells is most marked adjacent to vascular bundles in IAA-incubated shoots with this effect diminishing in cell files successively more removed from the bundles. This possibility then merits further study, especially to determine whether the active endogenous forms of auxin do in fact exert any regulatory control over directions of cell enlargement as well as planes of cell division in differentiating cells. This is the primary morphogenetic question arising from the present investigations that awaits further elucidation.

\section{Summary}

1. Intercalary growth in elongating internodes (p-1 locus) of excised shoots of Avena sativa is greatly modified by exogenously supplied IAA. Both transverse and longitudinal rates of growth of the internode are promoted by IAA in the light. The amount of promotion of growth by IAA is sufficient to overcome completely the inhibitory effects of light for older stages of development of the internode.

2. IAA exerts a marked inhibitory effect on intercalary growth in rapidly elongating p-1 internodes in the dark in contrast with its diametrically opposite effects in the light. The dark inhibition by IAA is most profound during early stages of development of the internode when the differential in growth between light and dark-incubated internodes is greatest. The amount of inhibition of growth by IAA in the dark is as great as the amount of promotion elicited by IAA in the light. 
3. Growth distribution studies show that IAA prolongs the duration of intercalary growth in older Avena internodes, particularly in the light. It promotes both longitudinal and transverse growth most strongly in the intercalary meristem (I. M.) locus of the internode but also has a promotion effect on growth above the I.M. locus.

4. IAA causes no profound changes in number of transverse asymmetric divisions in the intercalary meristem of the developing internode. It does cause significant changes in plane of cell division in the short cell derivatives of these asymmetric divisions and supplementary longitudinal divisions to occur in long epidermal cells which normally never divide once formed.

5. Augmented cell enlargement in longitudinal and transverse directions is the primary basis for promotion of linear and transverse growth in p-1 internode of Avena by IAA in the light. In the dark, in contrast, lateral cell expansion is promoted by IAA, but cell elongation is actually repressed. Epidermal cells in the intercalary meristem are more significantly affected, in terms of cell enlargement, by IAA than cells above this meristem or in internodes where the intercalary meristem is no longer active. The present studies strongly support the concept of differences in sensitivity of cells in developing internodes of Avena to IAA.

The author wishes to express his appreciation to Professors Hans Burström, Alfred S. Sussman and Conrad Yocum for stimulating and helpful discussions in connection with these investigations and in the preparation of this paper.

He also acknowledges with thanks the technical assistance of Mr. F. L. Kleinschmidt and Miss Joan Skibbe.

This work was supported under auspices of National Science Foundation grant GB 2688.

\section{References} Adamson, P.: Expansion and division in auxin-treated plant cells. - Can. J. Bot. 40: 719-
744. 1962.

Allsopp, A.: A comparison of the effects of 3-indolylacetic acid and 3-indolylacetonitrile on the development of sporelings of Marsilea in aseptic culture. - J. Exp. Bot. 5: 16-23.
1954 . Burström, H.: The influence of heteroauxin on cell growth and root development. - Ann.
Agr. Coll. Sweden 10: 209-240. 1942.

Castle, E. S.: The mode of growth of epidermal cells of the Avena coleoptile. - Proc. Natl. Acad. Sci. U.S. 41: 197-199. 1955.

Diehl, J. M., Gorter, C. J., Van Iterson, G., Jr. \& Kleinhoonte, A.: The influence of growth hormone on hypocotyls of Helianthus and the structure of the cell walls. - Rec. Trav. Bot. Neerl. 36: 709-798. 1939.

Green, P.: On mechanisms of elongation. - In Cytodifferentiation and Macromolecular

Synthesis. 21st Growth Symposium, pp. 203-234. Academic Press, Inc., New York. 1963.
Hashimoto, T.: Effects of light on the indoleacetic acid-induced growth of Pisum plant. -
Coll. Gen. Educ. Sci. Papers (Univ, Tokyo) 9. Coll. Gen. Educ. Sci. Papers (Univ. Tokyo) 9: 235-254. 1959.

Hejnowicz, $Z$.: The response of different parts of the cell elongation zone in root to external $\beta$-indolylacetic acid. - Acta Soc. Bot. Poloniae 30:25-42. 1961.

Jablonski, J. R. \& Skoog, F.: Cell enlargement and cell division in excised tobacco pith tissue. - Physiol. Plant. 7: 16-24. 1954. Jackson, W. T.: Effect of indoleacetic acid on rate of elongation of root hairs of Agrostis
alba L. - Ibid. 13: 36-45. 1960 . Kaufman, P. B.: Histological responses of the rice plant (Oryza sativa L.) to 2,4-D. -
Amer. J. Bot. 42:649-659. 1955 .

Physiol. Plant., 18, 1965 
- Katz, J. M. \& Yoder, M. E.: Growth responses of Avena stem segments to various sugars. - Nature 196: 1332-1333. 1962.

- Cassel, S. J. \& Adams, P. A.: On the nature of intercalary growth and cellular differentiation in internodal epidermis of Avena sativa L. - Bot. Gaz. 126. No. 1. 1965.

Levan, A.: Cytological phenomena connected with the root swelling caused by growth substances. - Hereditas 25: 87-96. 1939.

Miller, J. H. \& Miller, P. M.: Effects of auxin on cell enlargement in fern gametophytes: developmental stage of the cell and response to auxin. - Amer. J. Bot. 51:431-436. 1964.

Purves, W. K. \& Galston, A. W.: Interaction of sugars and auxin in pea epicotyl section growth. - Ibid. 47:665-669. 1960.

- \& Hillman. W. S.: Response of pea stem sections to indoleacetic acid, gibberellic acid, and sucrose as affected by length and distance from apex. - Physiol. Plant. 11: 29-35. 1958.

Ruge, U.: Untersuchungen über den Einfluss des Hetero-auxins auf das Streckungswachstum des Hypokotyls von Helianthus annuus. - Zeitsch. f. Bot. 31: 1-56. 1937.

Scott, T. K. \& Briggs, W. R.: Recovery of native and applied auxin from the dark-grown 'Alaska' pea seedling. - Amer. J. Bot. 50: 652-657. 1963.

Thompson, B. F. \& Miller, P. M.: The role of light in histogenesis and differentiation in the shoot of Pisum sativum. III. The internode. - Ibid. 50:219-227. 1963.

Thimann, K. V. \& Wardlaw, I. F.: The effect of light on the uptake and transport of indoleacetic acid in the green stem of the pea. - Physiol. Plant. 16: 368-376. 1963.

Torrey, J. G.: Cellular patterns in developing roots. - In Symp. Soc. Exp. Biol. 17. Cell Differentiation, pp. 285-314. 1963. 
This document is a scanned copy of a printed document. No warranty is given about the accuracy of the copy. Users should refer to the original published version of the material. 